\title{
Antiproliferative activity of chloroformic fractions from leaves and inflorescences of Ageratina gracilis
}

\author{
Gina Méndez-Callejas ${ }^{1 *}$, Jeanet Rodríguez-Mayusa², Myriam Riveros-Quiroga', Kelly Mahete-Pinilla', \\ Rubén Torrenegra-Guerrero²
}

${ }^{1}$ Programa de Medicina, Facultad de Ciencias de la Salud. Universidad de Ciencias Aplicadas y Ambientales. Bogotá, Colombia, ${ }^{2}$ Facultad de Ciencias, Universidad de Ciencias Aplicadas y Ambientales, Bogotá, Colombia

\section{A B S TR A C T}

To obtain a scientific basis and justification of plant domestication in the use of Ageratina gracilis, we did an in vitro study of the anticancer potential of extracts and fractions from its leaves and inflorescences. Firstly, cytotoxicity was evaluated against five human tumorigenic cell lines by MTT assay. Subsequently, the chloroformic fractions, considered the most cytotoxic were tested for genotoxicity by comet assay, morphological effects were analyzed by fluorescent microscopy, cell cycle arrest by flow cytometry and early apoptosis induction through fluorescein-5-isothiocyanate (FITC) labeled Annexin-V assay. Non-polar extracts with IC ${ }_{50}$ values of $<53 \mu \mathrm{g} / \mathrm{ml}$ showed a high cytotoxicity. The highest cytotoxicity was achieved by chloroformic fraction from petroleum ether extract of leaves and inflorescences and chloroformic fraction from ethanolic extract of leaves, displaying a significant inhibition of cell viability particularly on A549 cells with an $\mathrm{IC}_{50}$ value of $25.9 \mu \mathrm{g} / \mathrm{mL}$. Chloroformic fractions caused a high percent of DNA damage above 60 percent on A549 and MDAMB-231. The fractions also induced G1/S phase arrest of the cell cycle in A549 cells, furthermore it was confirmed the apoptotic activity chloroformic fraction from petroleum ether extract of inflorescences and chloroformic fraction from ethanolic extract of leaves on those cells by Annexin- $V$ assay. These preliminary results indicate that $A$. gracilis has an antiproliferative activity against cancer cells, being a starting point for forthcoming studies about the antineoplastic activity and its domestication conditions.

Keywords: Ageratina gracilis; Apoptosis; Cell cycle; Cell viability; Genotoxicity

\section{INTRODUCTION}

The use of natural products to suppress or prevent cancer progression has been a strategy used around the world particularly in developed countries with a wide biodiversity (Newman et al., 2016). Colombia is one of the countries with the highest diversity of plant species that can be used in treating diseases (Lizcano et al., 2014). Ageratina gracilis (Kunth) R.M. King \& H. Rob, is a specie that belongs to the family Asteraceae, it was formerly part of the Eupatorium genus but then classified within the genus Ageratina. It has different synonyms including Eupatorium caducisetum DC, Eupatorium epilobioides Kunth and Eupatorium gracile Kunth (Roskov et al., 2016). A. gracilis has been localized between 2000 and 3000 meters above sea level on Colombian moors (Garcia 1975), but factors such as, climate change, urbanization, among others have endangered the specie. A. gracilis is a herbaceous plant, about $20 \mathrm{~cm}$ high; erect stems and rounded at the bottom branches; green and alternate leaves on mature plants and whorls on the younger ones; by last leaflets have a length around 10 and $15 \mathrm{~mm}$. Corymb terminal inflorescences, white headed and heterogamous (Garcia., 1975). Previously, some flavonoids were isolated from flowers of $A$. gracile such as 3,5,4'-trihidroxi-7,8-dimetoxiflavone, 3,5,6,3'4'-pentahidroxi-6 metoxiflavone, 3,5,7,4'-tetrahidroxi,8-metoxiflavone, 3,5,6,7,3',4'-hexahidroxiflavone and 3,5,7,8,4'-pentahidroxiflavona ('Torrenegra et al., 1984) compounds that showed antioxidant activity.

Others species of Ageratina genus have been studied for anticancer activity, these are $A$. adenophora that showed inhibition of the cell proliferation against HCT-8 (colorectal adenocarcinoma), Bel-7402 (hepatocellular carcinoma), and A2780 (ovarian carcinoma) (He et al., 2008) A. pichinchensis presented in vitro cytotoxicity against some cancer cell lines as KB (nasopharyngeal

\section{${ }^{*}$ Corresponding author:}

Gina Méndez-Callejas, Programa de Medicina, Facultad de Ciencias de la Salud. Universidad de Ciencias Aplicadas y Ambientales. Bogotá, Colombia. E-mail: gmendez@udca.edu.co

Received: 28 September 2016; Revised: 15 December 2016; Accepted: 18 December 2016; Published Online: 11 January 2017 
carcinoma), UISO (squamous cell carcinoma of the cervix), OVCAR (ovarian carcinoma), and HCT-15 (colorectal carcinoma) (Romero et al., 2011) and recently it has been reported HeLa cells apoptosis induction by 9-oxo-10, 11-dehydroageraphorone, compound isolated from E. adenophorum (A. adenophora) (Liao et al., 2015).

The aim of the present study was to examine the cytotoxic activity, morphological changes, genotoxicity, cell cycle arrest and apoptosis induction on tumorigenic human cancer cell lines by $A$. gracilis extracts or fractions to establish if this specie has a possible anticancer potential and if its domestication can be justified.

\section{MATERIALS AND METHODS}

\section{Plant material collection and processing}

The plant was collected in Guasca Cundinamarca, Colombia, between 2800 and 3300 m.a.s.l, later identified at the Colombian National Herbarium as Ageratina gracilis (Kunth) R.M. King \& H. Rob COL 572755.

The dried ground plant material (leaves and inflorescences) were separately subjected to Soxhlet extraction first with petroleum ether and then with ethanol. The fractionation was done with these solvents in the following order: Petroleum ether, chloroform, ethyl acetate and ethanol thereby obtaining the different fractions. The cytotoxicity of fractions was performed and the exclusion of fractions was made according results, then, the study was focused in chloroformic fractions.

\section{Cell lines and culture conditions}

Culture cells were maintained as follow: HT29 (colorectal adenocarcinoma), and PC3 (prostate adenocarcinoma) in Dulbecco's modified Eagle's medium with high glucose (Lonza), supplemented with $10 \%$ (v/v) Fetal Bovine Serum (Biowest), 2 mM L-glutamine,

5,000 UI/ml penicillin and $5 \mathrm{mg} / \mathrm{ml}$ streptomycin. A549 (Lung: NSCLC alveolar basal epithelial- squamous), MDA-MB-231 (breast adenocarcinoma) and $\mathrm{SiHa}$ (cervical squamous cell carcinoma) were grown in RPMI 1640 medium (Lonza) supplemented with serum at 10\% (Biowest), $2 \mathrm{mM}$ L-glutamine, penicillin at a concentration of $5.000 \mathrm{UI} / \mathrm{ml}$ and streptomycin $5 \mathrm{mg} / \mathrm{ml}$. Mycoplasma contamination screen was done once per week with DAPI staining (Invitrogen) by fluorescence microscopy (Motic AE31).

\section{Inhibition of cell viability assay}

Antiproliferative activity was determined using the 3-(4, 5-methyl-thiazol-2-yl)-2, 5- diphenyl-tetrazoliumbromide (MTT) method (Kumar et al., 2014), with some modifications. Seven thousand cells were seeded per well in a 96-well plate and grown in a $5 \% \mathrm{CO}_{2}$ atmosphere at $37^{\circ} \mathrm{C}$ for $24 \mathrm{~h}$ before treatment. Cells dissolved in dimethyl sulfoxide (DMSO) (Sigma- Aldrich) were treated with extracts and fractions in concentrations of 2, 5, 10, 25, 50,100 and $200 \mu \mathrm{g} / \mathrm{mL}$. The maximum concentration of DMSO was $0.5 \%$ per treatment. After $24 \mathrm{~h}$ of incubation, MTT stock solution (Sigma-Aldrich) was dissolved in the corresponding medium without phenol red, and $100 \mu \mathrm{l}$ of a $0.5 \mathrm{mg} / \mathrm{mL}$ dilution was added per well and then incubated for $4 \mathrm{~h}$. Formazan products were solubilized with $100 \mu \mathrm{l}$ DMSO (Sigma-Aldrich). The optical density (OD) was determined with a wavelength of $570 \mathrm{~nm}$ by a 96 well plate reader (BioRad 680 Model). Vincristine sulphate (VCR) (Cayman) was used as positive control to determinate $\mathrm{IC}_{50}$ in MTT assay under the same conditions described above. The cell viability was expressed as percentage of non-inhibited cells at different concentrations by the extracts or fractions and the $\mathrm{IC}_{50}$ value was defined as the concentration where the extracts or fractions, caused a decrease of $50 \%$ of the cell viability. A non-linear regression was used to determine $\mathrm{IC}_{50}$ value.

\section{Morphological changes}

A morphological study was performed in order to examine the cellular damages occurred after exposure to the cytotoxic chloroformic fraction from petroleum ether extract of leaves and inflorescences and chloroformic fraction from ethanolic extract of leaves, of $A$. gracilis at half of the $\mathrm{IC}_{50}$ values determined before by MTT cell assay. One hundred thousand cells per well were seeded into a 24-well plate and grown in a $5 \% \mathrm{CO}_{2}$ atmosphere at $37^{\circ} \mathrm{C}$ for $24 \mathrm{~h}$ before treatment. Untreated and treated cells with active chloroformic fractions and VCR were fixed in absolute cold methanol for $10 \mathrm{~min}$, after $24 \mathrm{~h}$ of incubation, then in acetone for $20 \mathrm{~s}$ at $20{ }^{\circ} \mathrm{C}$. To evaluate integrity of the microtubules in the cells, a mouse anti-atubulin monoclonal antibody DM1A (Sigma-Aldrich) was used (Mendez et al., 2014), while mitochondria analysis was performed by using of rabbit anti-COX IV monoclonal antibody (Cell signaling). Cells were incubated with $0.2 \mu \mathrm{g} / \mathrm{mL}$ of the mouse anti- $\alpha$-tubulin or with $1.0 \mu \mathrm{g} / \mathrm{mL}$ of the rabbit anti-COX IV over night at $4{ }^{\circ} \mathrm{C}$ after blocking with $2 \%(\mathrm{w} / \mathrm{v}) \mathrm{BSA} / \mathrm{PBS}$. Cells were incubated with $2 \mu \mathrm{g} / \mathrm{mL}$ of Alexa Fluor 488 goat anti-mouse secondary antibody (Molecular Probes) or Texas Red anti-rabbit secondary antibody (Sigma Aldrich), both diluted in BSA/PBS at $2 \%(\mathrm{w} / \mathrm{v})$. Staining of DNA was done with $1.0 \mu \mathrm{g} / \mathrm{mL}$ of DAPI (Invitrogen). Slides mounted in antifade solution (Vectashield; Vector Laboratories) were monitored with epifluorescence Motic AE31 microscopy, captured with MoticCamPro 282A and analyzed with the Motic Image plus 2.0 software. 


\section{Genotoxicity assay (comet assay, single cell gel} electrophoresis)

A single cell gel electrophoresis (SCGE) or comet assay determined the chloroformic fractions genotoxic potential. DNA damage was quantified by measuring the displacement between the genetic material of the nucleus (comet head) and resulting tail (tail DNA). At least 50 cells were analyzed individually. As positive control for genotoxicity VCR was used (Recio et al., 2010). Tests were performed at $24 \mathrm{~h}$ after exposure to chloroformic fraction from petroleum ether extract of leaves and inflorescences and chloroformic fraction from ethanolic extract of leaves fractions and $\mathrm{VCR}$ at $\mathrm{IC}_{50}$ established before for each fraction. The procedure was performed according the instructions of the OxiSelect ${ }^{\mathrm{TM}}$ Comet Assay Kit, in TBE electrophoresis solution. Vista green DNA staining solution permitted to visualize the cells on epifluorescence microscopy AE31 MoticCamPro 282A. Images were captured and analyzed with Comet Score software expressing results as a DNA migration or tail DNA percent (1).

Tail DNA $\%=100 x$ Tail DNA Intensity/Cell DNA Inensity

\section{Cell cycle distribution}

Cell cycle distribution was measured on untreated and treated A549 cells with chloroformic fractions of $A$. gracilis, DMSO $0.5 \%$ is the negative control and VCR is a positive control for arresting in $\mathrm{G} 2 / \mathrm{M}$ phase. It was used a concentration corresponding to the $\mathrm{IC}_{50}$ value determined before by MTT assay. Cells were incubated during 24, 48 and $72 \mathrm{~h}$ at $37^{\circ} \mathrm{C}$ in a $5 \% \mathrm{CO}_{2}$ atmosphere. Cells were fixed dropwise with cold ethanol at $70 \%$ while gently vortexing, and incubated in the dark for $30 \mathrm{~min}$ with propidium iodide (PI) staining solution: $3.8 \mathrm{mM}$ sodium citrate, $50 \mu \mathrm{g} / \mathrm{mL}$ PI in PBS and RNase A stock solution: $10 \mu \mathrm{g} / \mathrm{ml}$ RNase A. DNA content measures were performed in a BD- FACS AriaTM cytometer. Cell distribution in the Sub-G1 (possible apoptosis), G1, S and G2/M phases of the cell cycle, was analyzed by using of Flowjo_V10 software.

\section{Annexin V-FITC detection of apoptosis}

A549 cells were plated at $1 \times 105$ cells per well into a 24-well plate. The next day, cells were treated with chloroformic fractions of A. gracilis, DMSO 0.5\% (negative control) and
VCR as positive control for apoptosis induction, and 100 $\mathrm{mM}$ of hydrogen peroxide $\left(\mathrm{H}_{2} \mathrm{O}_{2}\right)$ as positive control for necrosis (Teramoto et al., 1999). It was used a concentration that corresponded to the $\mathrm{IC}_{50}$ value determined before by MTT assay. Cells were incubated for $6 \mathrm{~h}$, and then stained with annexin V-FITC/PI (Cayman's Annexin V FITC/PI Assay Kit). Cells were examined by fluorescent microscopy using the filters for FITC (excitation/emission= $485 / 535 \mathrm{~nm}$ ) and for Texas Red (excitation/emission= 590/610 nm) in a fluorescent microscopy Motic AE31 and the images were captured in a MoticCamPro 282A.

\section{Statistical analysis}

The statistical analysis was performed on IBM SPSS 20 software. Assumptions of the parametric analysis were determined looking for a normal Gauss distribution by Shapiro- Wilk and Kolmogorov-Smirnoff test, with homogeneity of variances $(p>0.05)$. The values of percentage of DNA damage were submitted to analysis of variance (ANOVA), with post-hoc HSD-Tukey, Scheffé versus DNA damage determinated for VCR by Dunnett's test. All the experiments were performed in triplicate. Significant differences between cell responses were indicated as $* \mathrm{p}<0.05$ or $* * \mathrm{p}<0.01$

\section{RESULTS AND DISCUSSION}

Ageratina gracilis is considered a natural source for treatment of different diseases (García, 1975); however, there are not scientific reports related with its medicinal properties. The present study was aimed to evaluate the antiproliferative activity, and effects of extracts and fractions obtained from inflorescences and leaves of A. gracilis on human cancer cells, having as basis the knowing that this plant contains different compounds with possible biological activities as was previously reported (Torrenegra et al., 1984).

MT'T viability assay was used to evaluate cytotoxic effect. The results showed that non-polar extracts from inflorescences and leaves had a higher effect on cell viability compared with the polar extracts on all cell lines with $\mathrm{IC}_{50}$ values between 11.2 and $52.6 \mu \mathrm{g} / \mathrm{mL}$ (Table 1).

Table 1: The $\mathrm{IC}_{50}$ values of the polar and non-polar extracts and corresponding fractions from inflorescences and leaves of A. gracilis on cervix (SiHa), colon (HT29), lung (A549) breast (MDA MB-231) and prostate (PC3) cancer cell lines after 48 hours of incubation

\begin{tabular}{lccccc}
\hline Extract & \multicolumn{4}{c}{ IC $_{50} \boldsymbol{\mu g} / \mathbf{m l}$} \\
\cline { 2 - 6 } & SiHa & HT29 & A549 & MDAMB231 & PC-3 \\
\hline VCR control & 0.960 & 0.003 & 0.059 & 0.008 & $77.35 \pm 1.06$ \\
EtOH inflorescences (Et-I) & $41.14 \pm 1.02$ & $62.33 \pm 1.24$ & $74.56 \pm 0.95$ & $62.81 \pm 0.37$ & $72.46 \pm 0.47$ \\
EtOH leaves (Et-L) & $71.98 \pm 1.53$ & $53.05 \pm 0.82$ & $116.96 \pm 1.04$ & $58.44 \pm 0.78$ & $26.94 \pm 1.05$ \\
Petrol inflorescences (P-I) & $21.19 \pm 1.25$ & $12.67 \pm 1.13$ & $38.50 \pm 1.18$ & $14.72 \pm 0.69$ \\
Petrol leaves (P-L) & $12.91 \pm 0.92$ & $11.20 \pm 1.20$ & $34.80 \pm 1.15$ & $29.85 \pm 1.27$ \\
\hline
\end{tabular}

Values expressed in $\mu \mathrm{g} / \mathrm{mL} \pm$ SE. Vincristine sulphate was used as positive control for cytotoxicity 
The A549 lung cancer cells initially showed a high resistance to the extracts in general, with $\mathrm{IC}_{50}$ values between 34.8 and $117 \mu \mathrm{g} / \mathrm{ml}$; however the chloroformic fraction from petroleum ether extract of leaves and inflorescences, and chloroformic fraction derived from ethanolic extract from leaves had an important cytotoxicity on this cell line, with $\mathrm{IC}_{50}$ values of $17.5,23.7$ and $25.9 \mu \mathrm{g} / \mathrm{ml}$ respectively (Table 2 ). The other fractions showed a low cytotoxicity on all cell lines, reason why they were excluded of this study.

Based on the results of cytotoxicity, the study was directed towards the analysis of genotoxicity and apoptotic activity of the chloroformic fractions from petroleum ether extract of leaves and inflorescences and chloroformic fraction from ethanolic extract of leaves. The genotoxic activity, was evaluated by comet assay and the DNA damage was expressed as percentage of genetic material displaced from the nucleus or "comet head" resulting in a "comet tail" induced by treatments (Fig. 1a). According with the results a high percentage of DNA damage was exhibited by the cells exposed to the three chloroformic fractions indicating that these fractions have active compounds capable to inhibit the cell proliferation. The higher genotoxicity was achieved by the chloroformic fraction from petroleum ether extract of leaves on A549 and HT29 cells, with a percentage of DNA damage of $62 \%$ and $57 \%$ respectively, and significantly different to the effect of the positive control VCR $(\mathrm{p}<0.05)$, with a percentage of DNA damage of 33 $\%$ and $35.5 \%$ on A549 cells and HT29 cells respectively (Fig. 1b). The high percentage of DNA damage in the negative control cells exposed to $1 \% \mathrm{DMSO}$ was $1.5 \%$.

Morphological analysis performed on cells exposed to those fractions, by immunofluorescence microscopy was realized in order to confirm inhibitions of cell growth and estimate a possible apoptosis induction; changes in the microtubule integrity, nucleus, mitochondria, cell shape and size were detected. As it is known currently, the mode of death and morphological changes are dependent on the cell type, and the stimuli applied with other cell types (Ziegler et al., 2004). In the inhibition of microtubule dynamics, a persistent alteration of biological processes is induced which eventually leads to apoptosis (Mollinedo et al., 2003). In this study it was found a loss of the integrity of microtubules forming the cytoskeleton on all cells exposed to chloroformic fractions derived from petroleum ether extracts, and the most affected were $\mathrm{SiHa}$ and A549 cell lines in response to the chloroformic fraction from petroleum ether extract of inflorescences, chloroformic fraction from petroleum ether extract of leaves affected and A549 cells, the less effect on microtubule organization was observed in the cells exposed to chloroformic fraction from ethanolic extract of leaves (Fig. 2). Simultaneously with the microtubule destabilization, different nuclear phenotypes were induced by the treatments, finding in some cells as A549 and MDA-MB231, an initial increase in size thereof relative to the negative control, even with the positive control VCR, after 24 hours (Figs. 2 and 3). Previously, it was reported that VCR binds to DNA and chromatina on cancer cells (Mohammadgholi et al., 2013), according to this, the increase in the size of the nucleus could be related with the nuclear envelope disruption which allows vincristine, and perhaps components of chloroformic fractions, enter the nucleus. Another hypothesis is the induction of mitotic catastrophe, because it is known that different classes of cytotoxic agents can induce an abnormal mitosis that results in cell death (Mansilla et al., 2006), given by factors such as abnormal nuclei, nucleus enlarging, multipolar mitoses, or multiple nuclei, characteristic of mitotic catastrophe (Maskey et al., 2013), as it was observed in this study. On the other hand, the mitochondrial material was affected by chloroformic fractions, showing the shuttling of complex IV subunit (COX IV) from cytoplasm to the nucleus, as was observed in A549 and PC3 cells treated with chloroformic fraction from petroleum ether extract of leaves and in MDA-MB-231 cells exposed to chloroformic fraction from petroleum ether extract of inflorescences. These results could support an evidence of programmed cell death induction in A549 cells, according previous reports where mitochondrial proteins were translocated from mitochondria to the nucleus after apoptotic stimuli (Moreira et al., 2014). In addition, a decrease in the number of mitochondria was observed in A549 and MDA-MB-231 cells treated with chloroformic fraction from petroleum ether extract of leaves; A549 treated with chloroformic fraction from petroleum ether extract of inflorescences and MDA-MB-231 treated with chloroformic fraction from ethanolic extract of leaves (Fig. 3). All cell lines analyzed showed alterations by exposure to chloroformic fractions; however, according with the results, the most affected cells by treatments were A549. The size and complexity changes of that cell line was analyzed performing a basic flow cytometric analysis of the parameters forward-scatter area (FSC-A) and sidescatter area (SSC-A) data after $6 \mathrm{~h}$ of 50.000 events of treated or untreated cells. Fig. 4 shows the dot plot of subpopulations of A549 cells stained with PI. Synchronized and negative control cells were presented as normal in size and complexity; nevertheless, upon treatment with VCR, cells presented an increasing of FSC-A and SSC-A with the $87 \%$ of cells located in the Q2 subpopulation, between chloroformic fractions the chloroformic fraction from ethanolic extract of leaves caused the most significant alteration on light scatter properties: $77 \%$ of cells in Q2 (Fig. 4). 
Table 2: The IC $\mathrm{I}_{50}$ values of petroleum ether, chloroformic, ethyl acetate and ethanolic fractions from petroleum ether and ethanolic extracts of $A$. gracilis inflorescences and leaves, on SiHa, HT29, A549, MDA MB-231 and PC3 cancer cell lines after 48 hours of incubation

\begin{tabular}{|c|c|c|c|c|c|}
\hline \multirow[t]{2}{*}{ Fractions } & \multicolumn{5}{|c|}{$\mathrm{IC}_{50} \mu \mathrm{g} / \mathrm{ml}$} \\
\hline & $\mathrm{SiHa}$ & HT29 & A549 & MDAMB231 & PC-3 \\
\hline VCR-control & $0.960^{* *}$ & $0.003^{* *}$ & $0.059^{* *}$ & $0.008^{* *}$ & $0.054^{\star *}$ \\
\hline PI-Petrol & $>200$ & $>200$ & $>200$ & $>200$ & $>200$ \\
\hline $\mathrm{Pl}-\mathrm{CHCl}_{3}$ & $29.76 \pm 0.59^{*}$ & $28.35 \pm 0.84^{*}$ & $23.70 \pm 1.14^{*}$ & $29.04 \pm 0.83^{*}$ & $25.25 \pm 1.85^{*}$ \\
\hline PI-AcOEt & $74.44 \pm 0.17$ & $56.22 \pm 0.93$ & $90.55 \pm 0.36$ & $58.82 \pm 1.32$ & $79.44 \pm 1.12$ \\
\hline $\mathrm{Pl}-\mathrm{EtOH}$ & $116.43 \pm 0.80$ & $114.86 \pm 1.17$ & $120.22 \pm 1.09$ & $144.78 \pm 1.19$ & $>200$ \\
\hline Etl-Petrol & $>200$ & $>200$ & $>200$ & $>200$ & $>200$ \\
\hline Etl-CHCl ${ }_{3}$ & $93.97 \pm 0.18$ & $85.60 \pm 1.05$ & $109.44 \pm 0.56$ & $149.49 \pm 1.93$ & $125.44 \pm 1.65$ \\
\hline Etl-AcOEt & $>200$ & $>200$ & $>200$ & $>200$ & $>200$ \\
\hline Etl-EtOH & $>200$ & $>200$ & $>200$ & $>200$ & $145.38 \pm 1.32$ \\
\hline PL-Petrol & $>200$ & $>200$ & $>200$ & $>200$ & $>200$ \\
\hline $\mathrm{PL}-\mathrm{CHCl}_{3}$ & $18.81 \pm 1.13^{*}$ & $86.22 \pm 0.94$ & $68.99 \pm 1.21$ & $170.15 \pm 1.05$ & $81.03 \pm 1.09$ \\
\hline PL-AcOEt & $>200$ & $>200$ & $>200$ & $>200$ & $>200$ \\
\hline PL-EtOH & $118.05 \pm 1.13$ & $86.22 \pm 0.94$ & $68.99 \pm 1.21$ & $170.15 \pm 1.05$ & $81.03 \pm 1.09$ \\
\hline EtL-Petrol & $>200$ & $>200$ & $>200$ & $>200$ & $>200$ \\
\hline EtL- $\mathrm{CHCl}_{3}$ & $32.86 \pm 1.02 *$ & $30.48 \pm 0.65^{*}$ & $25.96 \pm 1.12^{*}$ & $40.84 \pm 0.77$ & $64.14 \pm 0.47$ \\
\hline EtL-AcOEt & $125.48 \pm 0.32$ & $>200$ & $>200$ & $>200$ & $>200$ \\
\hline EtL-EtOH & $>200$ & $149.50 \pm 1.25$ & $>200$ & $>200$ & $>200$ \\
\hline
\end{tabular}

Values are expressed in $\mu \mathrm{g} / \mathrm{mL} \pm S E$. Sample with highest cytotoxicity $\left({ }^{* *} \mathrm{p}<0.01\right),\left({ }^{*} \mathrm{p}<0.05\right)$

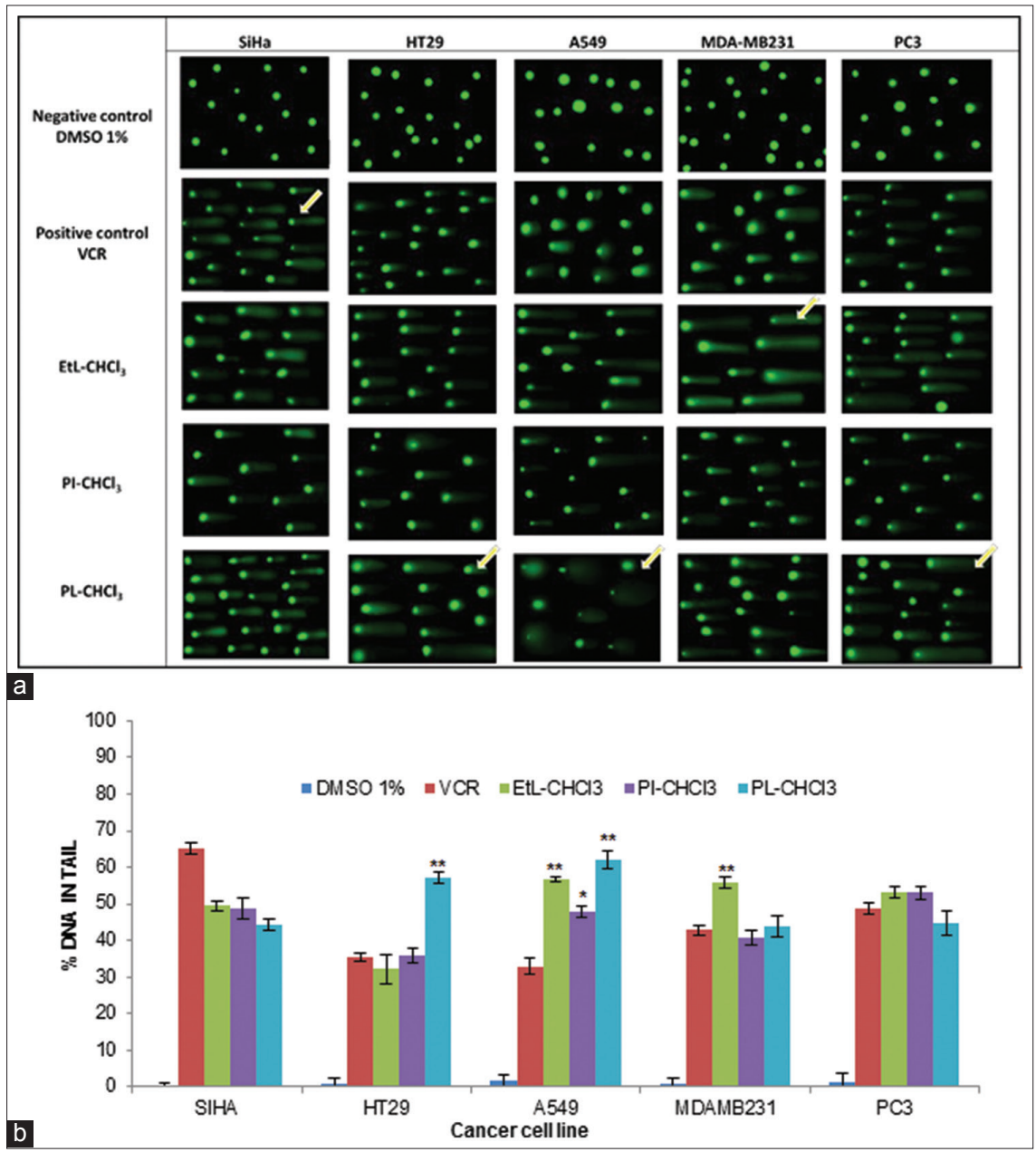

Fig 1. Genotoxic activity of chloroformic fractions from petroleum ether and ethanolic extracts of inflorescences and leaves of $A$. gracilis on SiHa, HT29, A549, MDA MB-231 and prostate PC3 cancer cell lines after 24 hours of incubation, (a) Comet assay fluorescent images. Nuclei stained with vista green, (b) Percentage of DNA damage, according analysis of parameters by comet score software. Significant values according to ANOVA test, ${ }^{*} p<0.05,{ }^{* *} p<0.01$. 


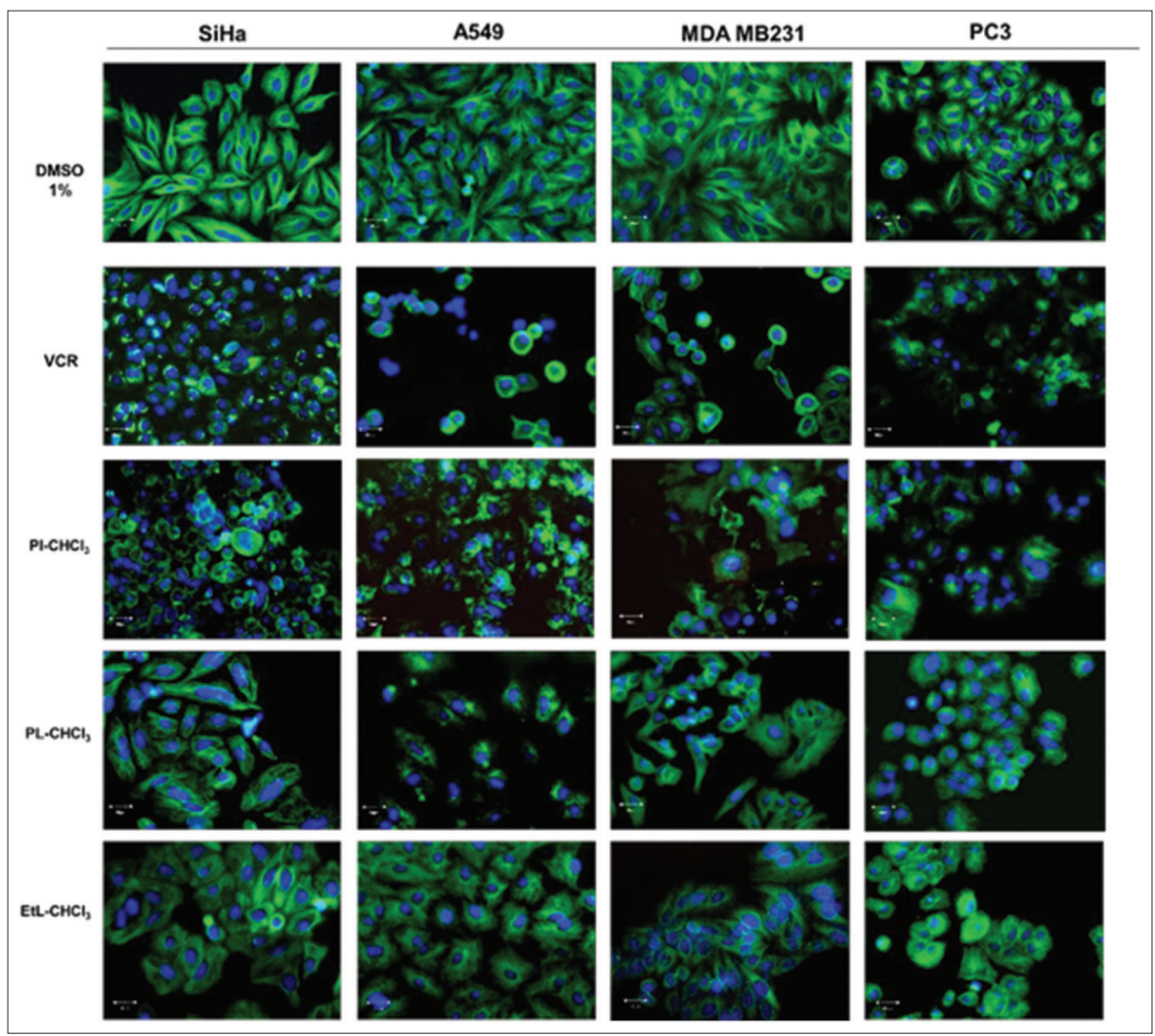

Fig 2. Microtubular (in green) and nuclear effects (in blue) on SiHa, HT29, A549, MDA MB-231 and prostate PC3 cancer cell lines after 24 hours of incubation with chloroformic fractions from petroleum ether and ethanolic extracts of inflorescences and leaves of $A$. gracilis.

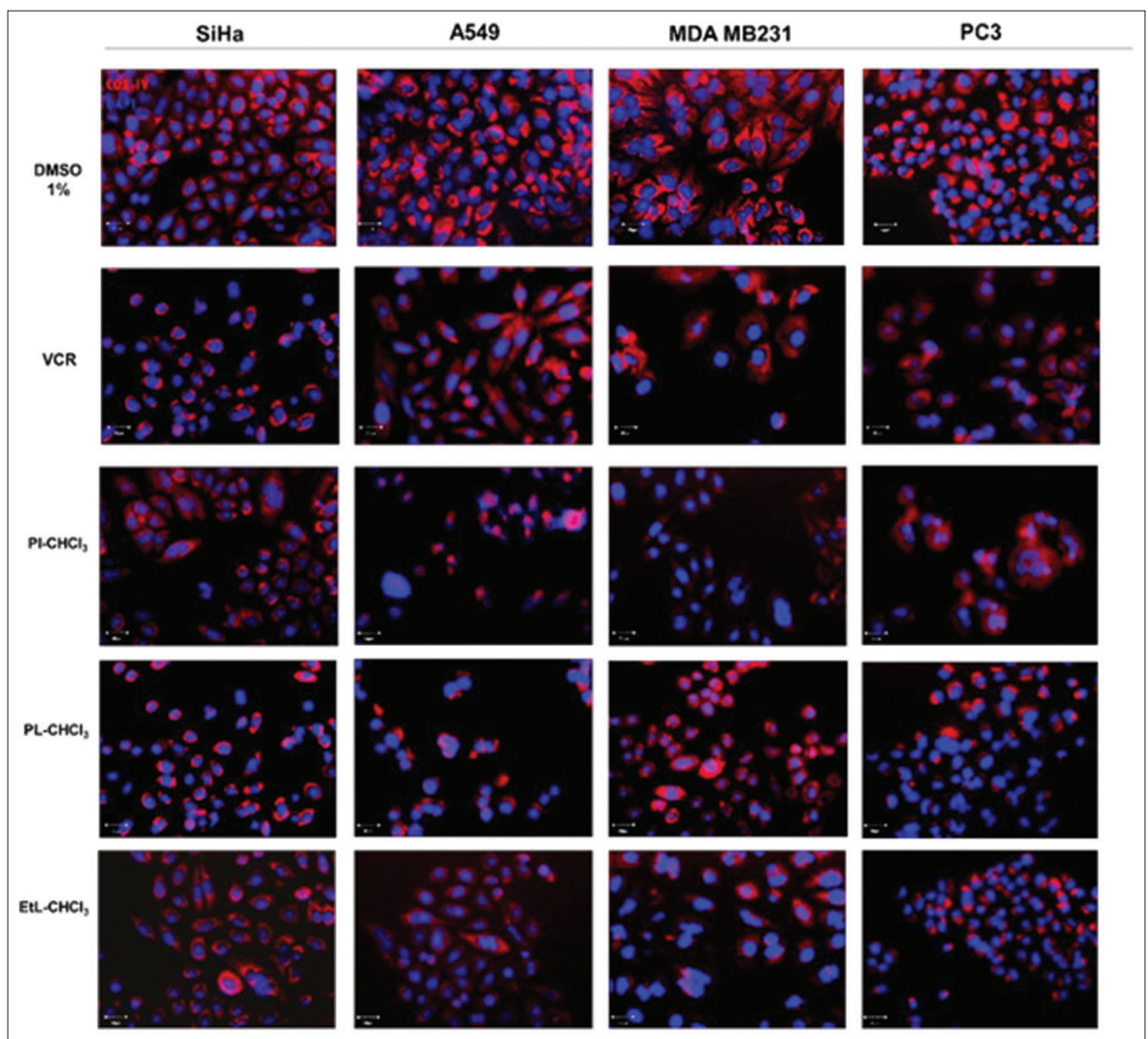

Fig 3. Mitochondrial effects on SiHa, HT29, A549, MDA MB-231 and prostate PC3 cancer cell lines after 24 hours of incubation with chloroformic fractions from petroleum ether and ethanolic extracts of inflorescences and leaves of $A$. gracilis. In red, COX IV protein localization as a marker of mitochondria integrity, in blue the nuclear staining. 
On the other hand, a normal distribution in the cell cycle phases was observed with the negative controls of A549 cells. The synchronized cells showed a high population in G1 phase $>80 \%$ which was decreasing with the progress of incubation time with DMSO vehicle, but without affection in the normal development. The number of cells in Sub-G1 not exceed 2\% during 72 hours of incubation. Vincristine sulfate, as expected, produced an arrest in $\mathrm{G} 2 / \mathrm{M}$ phase of the cell cycle of A549 cells, avoiding cell proliferation and hence causing cell death (Poruchynsky et al., 2015), as was evidenced in a time dependent manner of drug treatment. Instead, the chloroformic fraction from petroleum ether extract of inflorescences, chloroformic fraction from petroleum ether extract of leaves and chloroformic fraction from ethanolic extract of leaves, caused cell growth inhibition of A549 cells by blocking the G1 phase to S phase in the cell cycle (Fig. 5). However, cells treated with chloroformic fraction from petroleum ether extract of leaves decay aggressively at $48 \mathrm{~h}$ indicating that cell cycle arrest induced by this fraction, occurred during a short time before imminent cell death. A similar behavior was evidenced on cells exposed to chloroformic fraction from petroleum ether extract of inflorescences but at $72 \mathrm{~h}$, indicating that these fractions could be a highly active compound that causes rapid decrease in cell viability.

The results of different test showed that treatments given with chloroformic fractions from petroleum ether extract of inflorescences, chloroformic fraction from petroleum ether extract of leaves, and chloroformic fraction from ethanolic extract of leaves are impeding cells elapse to phases of DNA synthesis and cell division inducing cell death; but it is unknown if this cell death is due to the apoptosis or necrosis process on A549 lung cancer cells. In this respect, apoptosis induction achieved by chloroformic

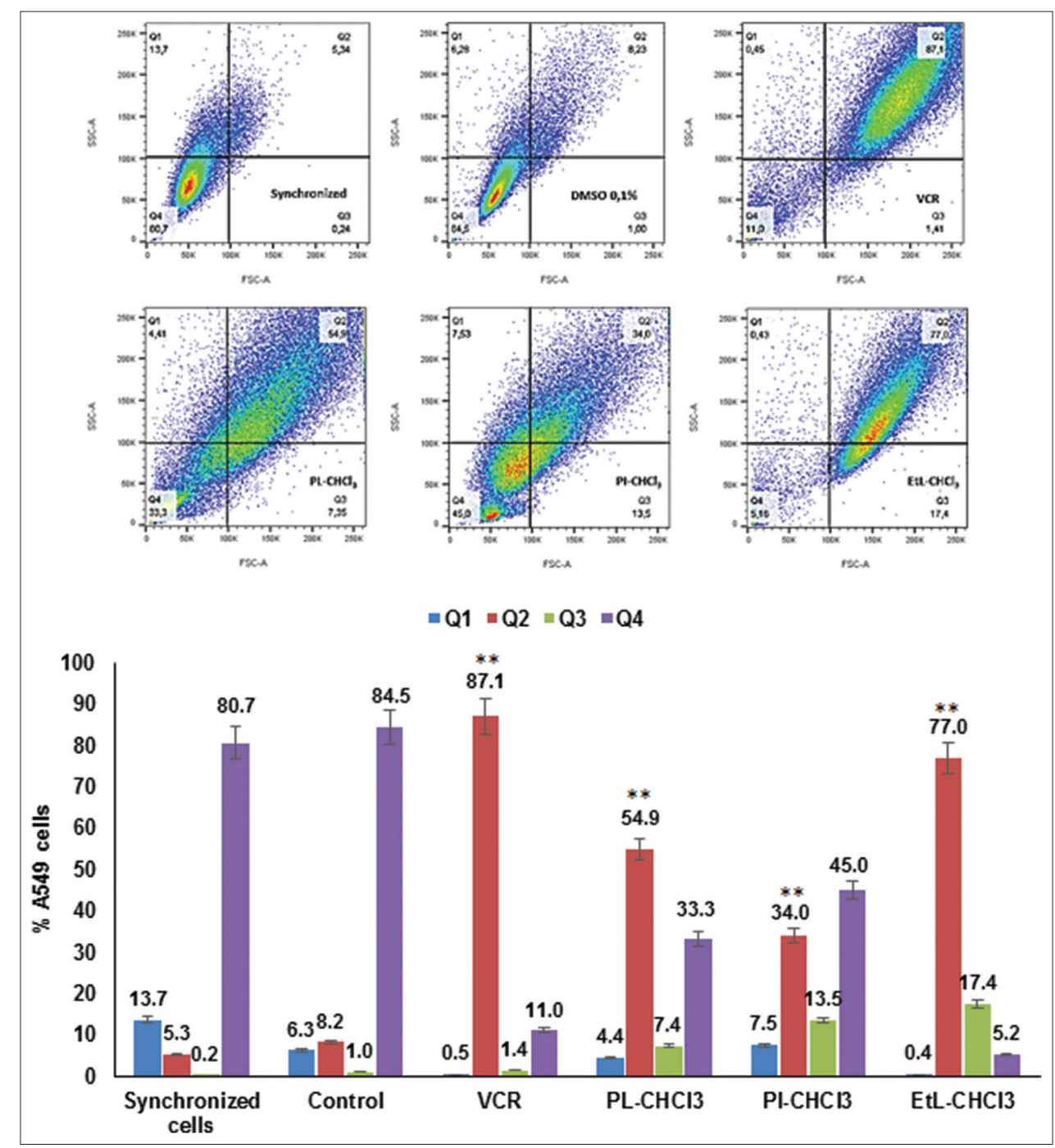

Fig 4. Front and side scatters representing changes in size and complexity of the A549 cells after 6 hours of treatment with chloroformic fractions from petroleum ether and ethanolic extracts of inflorescences and leaves of $A$. gracilis. Cells were stained with $\mathrm{PI}$ and parameters were analyzed using the FlowJo_V10 software. Significant differences in values of cells in Q2 according to ANOVA test, $p>0.01^{* *}$. 


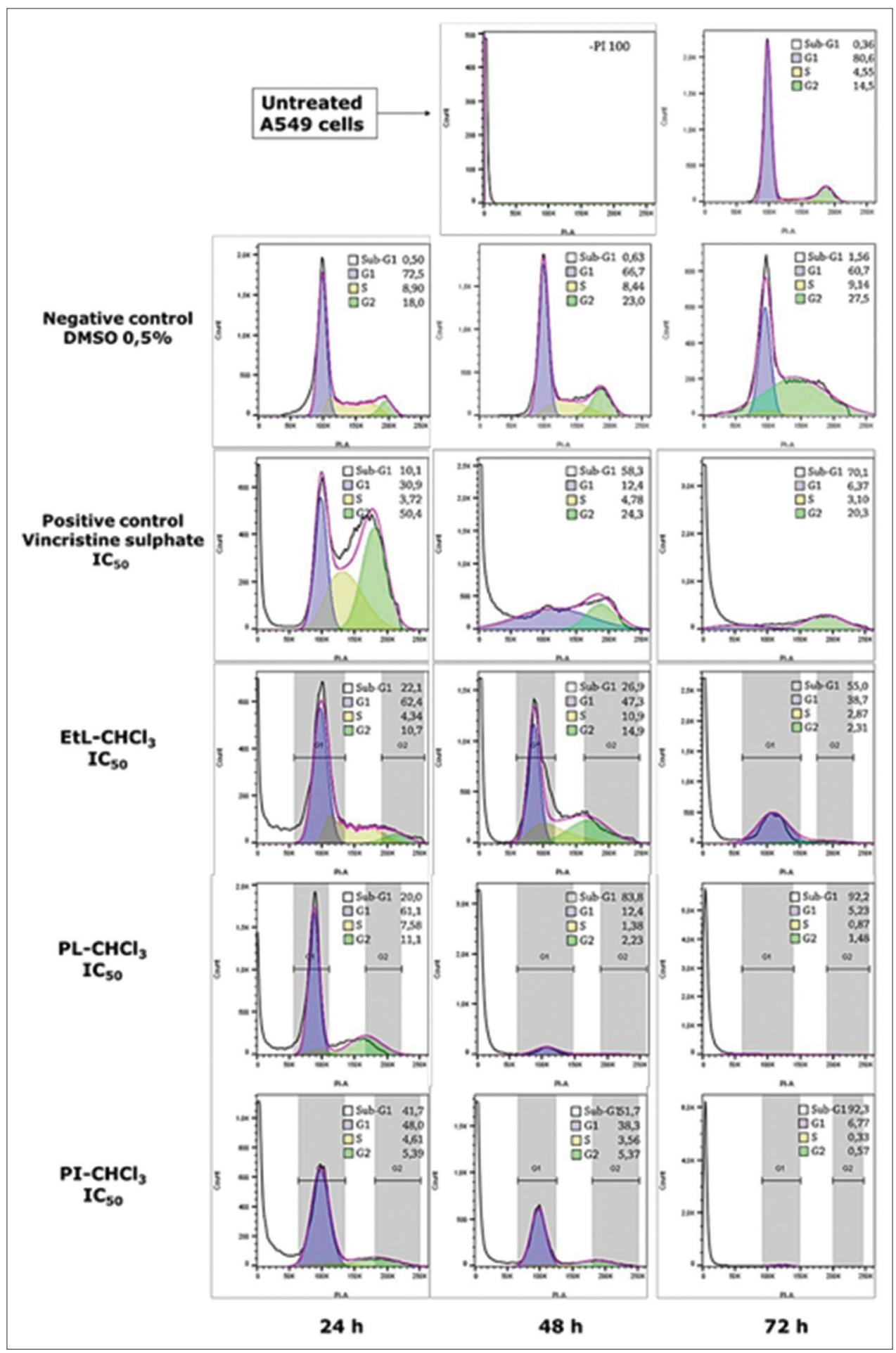

Fig 5. A549 cells distribution in the phases of the cell cycle after treatments with DMSO $1 \%$ (negative control), VCR (positive control for arresting in G2/M phase), and Chloroformic fractions of $A$. gracilis. Cells were incubated by 24,48 and $72 \mathrm{~h}$, and stained with PI. Cells distribution in the Sub-G1 (possible apoptosis), G1, S and G2/M phases of the cell cycle, was analyzed by using of FlowJo_V10 software.

fractions on lung cancer cells A549 was evaluated by detection of Annexin-V/FITC assay after $6 \mathrm{~h}$ of treatments at $\mathrm{IC}_{50}$ established before by MT'T assay. Apoptotic activity of two chloroformic fractions was confirmed by the detection of phosphatidil serine residues translocated to the extracellular membrane, with fluorescently labeled Annexin-V/FITC.

As it is known, PI has the ability to enter a cell when it loses the permeability of the membrane, indicating late 


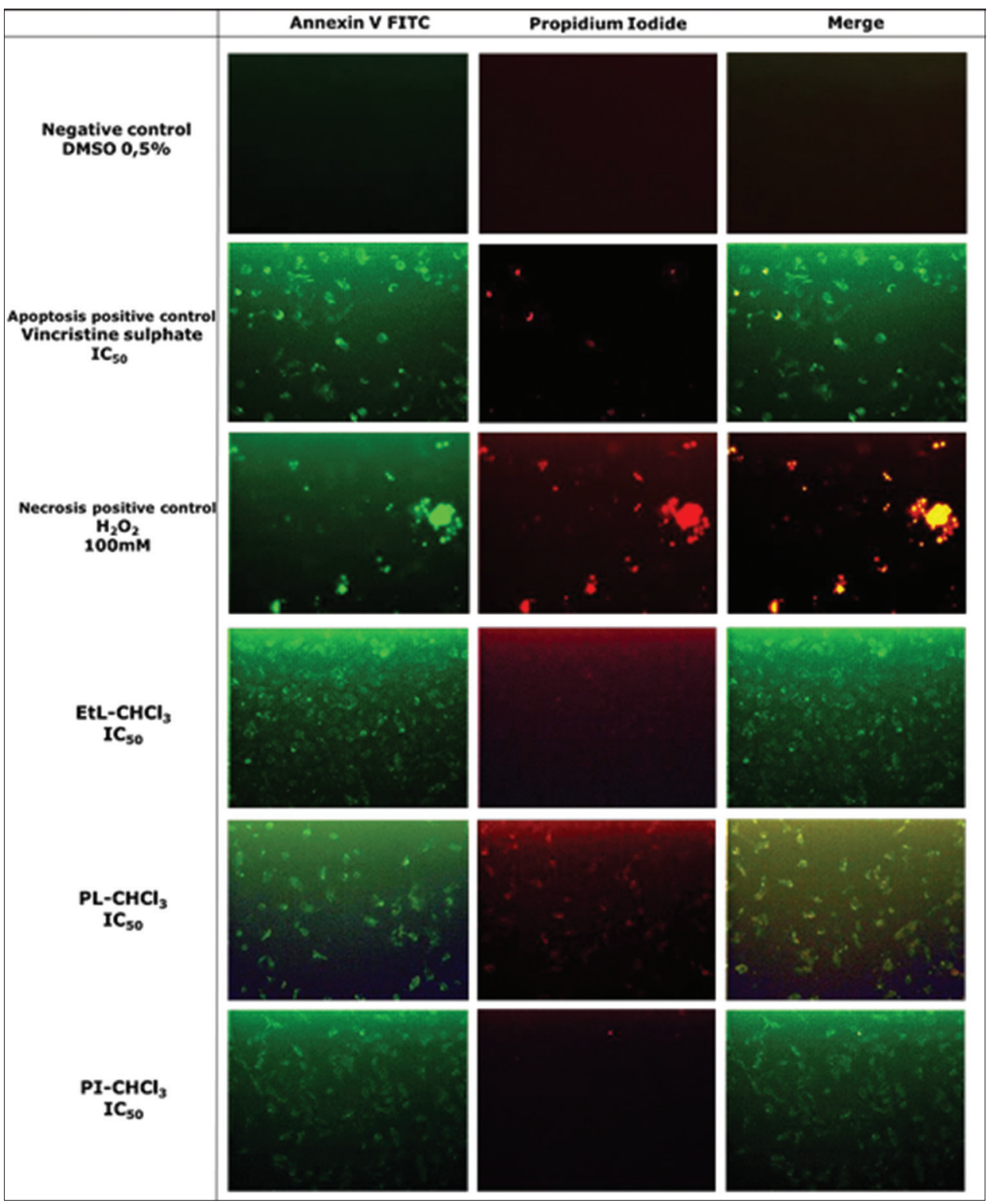

Fig 6. Apoptotic effect of chloroformic fractions from A. gracilis at the $\mathrm{IC}_{50}$ concentration on $\mathrm{A} 549$ cancer cells, determined by Annexin $\mathrm{V}-\mathrm{FITC}$ (green channel) six hours after treatment. PI (red channel) was used to locate dead cells. Cells treated with vehicle only (DMSO $0.5 \%$ ) served as a negative control, while VCR was used as a positive control for apoptosis, and $100 \mathrm{mM} \mathrm{H}_{2} \mathrm{O}_{2}$ as a positive control for necrosis.

apoptosis or necrosis, therefore, PI does not stain live or early apoptotic cells due to the presence of an intact plasma membrane (Rieger et al., 2011). In this respect, the results indicated that the chloroformic fractions from petroleum ether extract of inflorescences, and chloroformic fraction from ethanolic extract of leaves induced early pro-apoptotic response on A549 cancer cell lines (Fig. 6). By the contrary, cells exposed to chloroformic fractions from petroleum ether extract of leaves showed PI staining, indicating late apoptosis at only $6 \mathrm{~h}$ of treatment, confirming the rapid induction of cell death seen before on cell cycle analysis after $48 \mathrm{~h}$ of treatment with this fraction. Positive control cells (VCR treated) showed early apoptosis, only a few cells showed late apoptosis. Cells treated with peroxide hydrogen, were rapidly labeled with both, Annexin V FITC and PI showing a typical cellular death by late apoptosis or necrosis (Brauchle et al., 2014).

\section{CONCLUSIONS}

In conclusion, this study confirms that Ageratina gracilis has anticancer properties on A549, MDA-MB231, HT29, SiHa and PC3 cells. The results demonstrated that chloroformic fractions from ethanolic extract of leaves, and of petroleum ether extract of inflorescences, have a high antiproliferative and genotoxic effect on A549 cell line, additionally, inducing G1 cell cycle arrest, and apoptosis, different to chloroformic fraction from petroleum ether extract of 
leaves, that caused apparently non-programming cell death. The data obtained is a starting point for forthcoming studies focused in the elucidation of active components present in these fractions.

\section{ACKNOWLEDGEMENTS}

This work was financially supported by Colciencias and Universidad de Ciencias Aplicadas y Ambientales. U.D.C.A, in contract 599-2014.

\section{Authors' contributions}

G.M: Supervision and participation in all biological analysis and writing of the article. J.R: Isolation of extracts and fractions from plant. M.R: Did genotoxic test K.M: Participated in experiments of fluorescent microscopy R.T: Plant recollection and supervision of phytochemistry experiments.

\section{REFERENCES}

Brauchle, E., S. Thude, S. Y. Brucker and K. Schenke-Layland. 2014. Cell death stages in single apoptotic and necrotic cells monitored by Raman microspectroscopy. Sci. Rep. 15: 4698-4705.

García, H. 1975. Flora Medicinal de Colombia, Tomo IIIrd ed. Imprenta Nacional, Bogotá, pp. 345-350.

Kumar, M., V. Dhiman, R. Choudhary and A. Chikara. 2014. Anticancer activity of hydroalcoholic extracts from Paris polyphylla rhizomes against human A549 lung cancer cell lines using MTT assay. Int. Res. J. Pharm. 5: 290-294.

He, L., J. Hou, M. Gan, J. Shi, S. Chantrapromma, H. K. Fun, I. D. Williams and H. H. Sung. 2008 Cadinane sesquiterpenes from the leaves of Eupatorium adenophorum. J. Nat. Prod. 71: 1481-1488.

Liao, F., Y. Hu, L. Wu, H. Tan, B. Luo, Y. He, Y. Qiao, Q. Mo, Y. Wang, Z. Zuo, J. Deng and Y. Wei. 2015. Induction and mechanism of HeLa cell apoptosis by 9-oxo-10, 11-dehydroageraphorone from Eupatorium adenophorum. Oncol. Rep. 33: 1823-1827.

Lizcano, L. J., M. Siles, J. Trepiana, M. L. Hernández, R. Navarro, M. B. Ruiz-Larrea and J. Ruiz-Sanz. 2014. Piper and Vismia species from Colombian Amazonia differentially affect cell proliferation of hepatocarcinoma cells. Nutrients. 7: 179-195.

Mansilla, S., M. Bataller and J. Portugal. 2006. Mitotic catastrophe as a consequence of chemotherapy. Anticancer Agents Med. Chem. 6: 589-602.

Maskey, D, S. Yousefi, I. Schmid, I. Zlobec, A. Perren, R. Friis and H.
U. Simon. 2013. ATG5 is induced by DNA-damaging agents and promotes mitotic catastrophe independent of autophagy. Nat. Commun. 4: 2130.

Mendez, G. M., S. Leone, C. Tanzarella and A. Antoccia. 2014. Combretastatin A-4 induces p53 mitochondrial-relocalisation independent-apoptosis in non-small lung cancer cells. Cell. Biol. Int. 38: 296-308.

Mohammadgholi, A., A. Rabbani-Chadegani and S. Fallah. 2013. Mechanism of the interaction of plant alkaloid vincristine with DNA and Chromatin: Spectroscopic study. DNA Cell Biol. 32: 228-235.

Mollinedo, F. and C. Gajate. 2003. Microtubules, microtubuleinterfering agents and apoptosis. Apoptosis. 8: 413-450.

Moreira, A. C., A. F. Branco, S. F. Sampaio, T. Cunha-Oliveira, T. R. Martins, J. Holy, P. J. Oliveira and V. A. Sardão. 2014. Mitochondrial apoptosis-inducing factor is involved in doxorubicin- induced toxicity on $\mathrm{H} 9 \mathrm{c} 2$ cardiomyoblasts. Biochim. Biophys. Acta. 12: 2468-2478.

Newman, D. J. and G. M. Cragg. 2016. Natural products as sources of new drugs from 1981 to 2014. J. Nat. Prod. 79: 629-661.

Poruchynsky, M., E. Komlodi-Pasztor, S. Trostel, J. Wilkerson, M. Regairaz, Y. Pommier, X. Zhang, T. Kumar, R. Robey, M. Burotto, D. Sackett, U. Guha and A. T. Fojoa. 2015. Microtubuletargeting agents augment the toxicity of DNA-damaging agents by disrupting intracellular trafficking of DNA repair proteins. Proc. Natl. Acad. Sci. U S A. 112: 1571-1576.

Recio, L., C. Hobbs, W. Caspary and K. L. Witt. 2010. Dose-response assessment of four genotoxic chemicals in a combined mouse and rat micronucleus (MN) and comet assay protocol. J. Toxicol. Sci. 35: 149-62.

Rieger, A. M., K. L. Nelson, J. D. Konowalchuk and D. R. Barreda. 2011. Modified annexin V/propidium iodide apoptosis assay for accurate assessment of cell death. J. Vis. Exp. 24: 2597.

Romero, O., A. Zamilpa, A. Ramos, D. Alonso-Cortés, J. E. Jiménez, M. E. Huerta and J. Tortoriello. 2011. Effect on the wound healing process and in vitro cell proliferation by the medicinal Mexican plant Ageratina pichinchensis. Planta Med. 77: 979-83.

Roskov, Y., L. Abucay, T. Orrell, D. Nicolson, T. Kunze, C. Flann, N. Bailly, P. Kirk, T. Bourgoin, R., E. DeWalt, W. Decock and A. DeWever. 2016. GCC: Global compositae checklist. In: Species 2000 and ITIS Catalogue of Life. Digital Resource. Available from: http://www.catalogueoflife.org/col/details/species/id/4eee6 fe3fbf2731f796f81ea2faae5ad. [Last accessed on 2016 Sep 19].

Teramoto, S., T. Tomita, H. Matsui, E. Ohga, T. Matsuse and Y. Ouchi. 1999. Hydrogen peroxide-induced apoptosis and necrosis in human lung fibroblasts: Protective roles of glutathione. J. Pharmacol. 79: 33-40.

Torrenegra, R., J. Pedrozo and S. Escarria. 1984. Flavonoides de Eupatorium gracile. Rev. Latinoamer. Quim. 15: 129-130.

Ziegler, U. and P. Groscurth. 2004. Morphological features of cell death. News Physiol. Sci. 19: 124-128. 